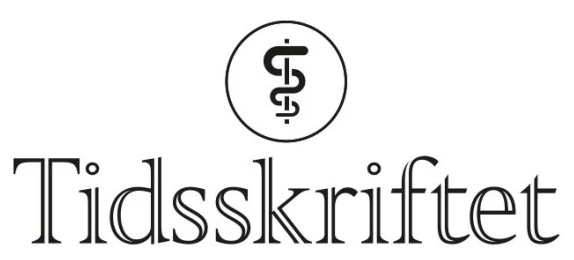

DEN NORSKE LEGEFORENING

\title{
Pasienttilstrømming i et akuttmottak i påvente av covid-19-pandemien
}

KORT RAPPORT

\section{LARS PETTER BJØRNSEN}

lars.p.b.w.bjornsen@ntnu.no

Akutten

Klinikk for akutt-og mottaksmedisin

St. Olavs hospital

og

Institutt for sirkulasjon og bildediagnostikk

NTNU - Norges teknisk-naturvitenskapelige universitet

Lars Petter Bjørnsen er spesialist i akutt- og mottaksmedisin, overlege og førsteamanuensis.

Forfatteren har fylt ut ICMJE-skjemaet og oppgir ingen interessekonflikter.

\section{LARS EIDE NAESS-PLEYM}

\section{Akutten}

og

Akuttmedisinsk fagavdeling

Klinikk for akutt- og mottaksmedisin

St. Olavs hospital

Lars Eide Næss-Pleym er IKT-rådgiver og doktorgradsstipendiat.

Forfatteren har fylt ut ICMJE-skjemaet og oppgir ingen interessekonflikter.

\section{JOSTEIN DALE}

Akuttmedisinsk fagavdeling

Klinikk for akutt-og mottaksmedisin

St. Olavs hospital

Jostein Dale er overlege og leder for fagavdelingen.

Forfatteren har fylt ut ICMJE-skjemaet og oppgir ingen interessekonflikter.

\section{LARS ERIK LAUGSAND}

Akutten

Klinikk for akutt- og mottaksmedisin

St. Olavs hospital

og

Institutt for sirkulasjon og bildediagnostikk

NTNU - Norges teknisk-naturvitenskapelige universitet

Lars Erik Laugsand er assisterende klinikksjef og overlege.

Forfatteren har fylt ut ICMJE-skjemaet og oppgir ingen interessekonflikter. 
Akuttmottaket i Trondheim har forberedt seg på storinnrykk av pasienter smittet med sars$\mathrm{CoV}$-2-virus. I en studie sammenlignet vi pasienter i akuttmottaket de første ukene av pandemien i Norge (uke 11 og uke 12) med gjennomsnittlig pasienttilstrømming.

\section{MATERIALE OG METODE}

Data fra pasienter i akuttmottaket ved St. Olavs hospital i perioden 6.1.2020-22.3.202o ble innhentet fra akuttmottakets database. Logistiske pasientdata som omhandlet pasientantall, medisinsk problemstilling, liggetid i akuttmottaket, hastegrad, smitteisolering og behandlingsnivå ble analysert.

\section{RESULTATER}

I uke 12 ble 331 pasienter henvist til akuttmottaket, i motsetning til gjennomsnittet på 541 pasienter i uke 2-10, en reduksjon på 39\%. Det var en generell reduksjon av alle pasientgrupper, men spesielt for poliklinisk håndterte pasienter. I uke 12 var det 56 flere isolerte pasienter med mistenkt/potensielt smittsom infeksjonssykdom (187\%) sammenlignet med gjennomsnittet for uke 2-10, og liggetiden for smitteisolerte pasienter var nesten to timer lenger enn for andre pasienter.

\section{FORTOLKNING}

Det var en reduksjon av pasienttilstrømming til akuttmottaket de første ukene av pandemien. Andelen smitteisolerte pasienter $\emptyset \mathrm{kte}$, og liggetiden for isolerte pasienter var høyere enn for andre pasienter. Det forventes at reduksjonen i pasienttilstrømmingen er midlertidig, og akuttmottaket ved St. Olavs hospital venter på storinnrykk av pasienter med mistenkt covid-19-sykdom.

\section{HOVEDFUNN}

I løpet av de første ukene av covid-19-pandemien i Norge var det en generell reduksjon i antall pasienter henvist til akuttmottaket.

Reduksjonen var størst blant pasienter med lav hastegrad og pasienter som normalt håndteres poliklinisk i akuttmottaket.

Antall smitteisolerte pasienter $ø$ kte, og disse hadde betydelig lengre oppholdstid i akuttmottaket.

Den nåværende pandemien, forårsaket av sars-CoV-2-viruset, ble spådd å nå Norge kort tid etter utbruddet i Kina (1). Etter vedtaket fra regjeringen om nærmest å stenge ned Norge 12. mars (uke 11) har akuttmottakene forberedt seg på storinnrykk av smittede pasienter. Akuttmottaket ved St. Olavs hospital forbereder verste fall- scenarioer, men opplever nå at det er stille før stormen. Ingen helsepersonell i akuttmottaket er i karantene, men per 14. april 2020 har totalt 15 ansatte ved St. Olavs hospital covid-19-sykdommen og 83 er i karantene eller hjemme med luftveissymptomer (2).

Akuttmottaket ved St. Olavs hospital har de siste årene sett en gradvis økning $\mathrm{i}$ pasienttilstrømming (3). Pasientpopulasjonen består primært av pasienter eldre enn 15 år. Alle hastegradbestemmes etter RETTS-systemet (Rapid Emergency Triage and Treatment System) (4), der pasientene kategoriseres som rød, oransje, gul eller grønn etter antatt alvorlighetsgrad. Røde pasienter skal tilsees umiddelbart av lege, mens grønne pasienter kan ved samtidskonflikter vente på legetilsyn. Barn og voksne med problemstillinger som sorterer under gynekologi og obstetrikk, øye og øre-nese-hals tas derimot som hovedregel imot ved egne mottak eller egen poliklinikk (3). 
Vi ønsket med denne studien å sammenligne pasienttilstrømming i uke 11 og 12, da St. Olavs hospital trappet opp forberedelsene for pandemien, med gjennomsnittet av de foregående ukene (uke 2-10).

\section{Materiale og metode}

Data fra alle pasienter som ankom akuttmottaket ved St. Olavs hospital i perioden 6. januar 2020 til 22. mars 2020 (uke 2-10), ble hentet fra akuttmottakets database (Akuttdatabasen, Helse-Vest IKT, versjon 1.5.5., Stavanger). Vi valgte denne tidsperioden da vi antar at den er representativ for stabil pasienttilstrømming uten påvirkning av høytider. Logistiske data som pasientantall, medisinsk problemstilling, liggetid i akuttmottaket, hastegrad, smittestatus og behandlingsnivå, ble importert og behandlet i Statistical Package for the Social Sciences (SPSS) versjon 25. Deretter ble relevante data overført til Microsoft Excel 2016 for grafiske fremstillinger. Studien var godkjent av personvernombud (ESA-nr. 16/9114) og lagt frem for for Regional komité for medisinsk og helsefaglig forskningsetikk (REK 2016/1813).

\section{Resultater}

I uke 11 og uke 12 ble henholdsvis 426 og 331 pasienter henvist til akuttmottaket, i motsetning til gjennomsnittet på 541 pasienter i uke 2-10. Dette tilsvarer en reduksjon på 115 pasienter (21\%) i uke 11 og 210 pasienter (39\%) i uke 12 (figur 1). Reduksjonen var tydelig allerede i midten av uke 11 (figur 2).

Pasienttilstrømming Smitteisolerte pasienter

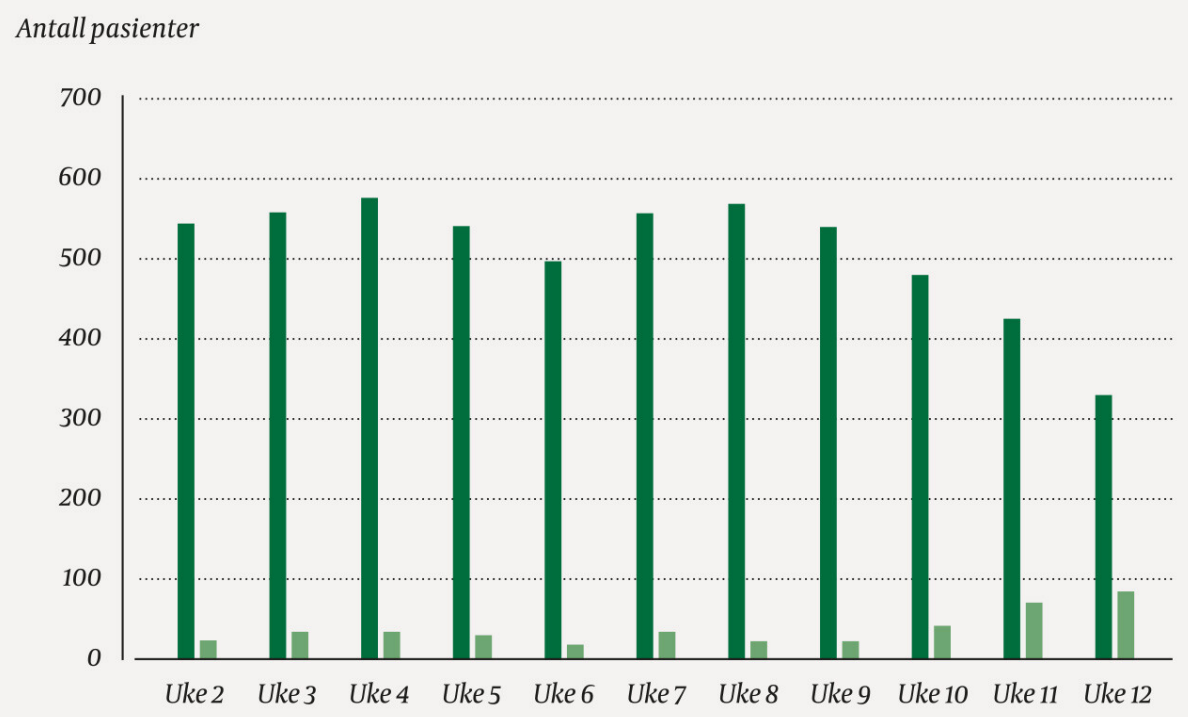

Figur 1 Oversikt over antall pasienter tilsett i akuttmottaket ved St. Olavs hospital per uke i første kvartal 2020 og antall ukentlige pasienter som ble isolert i akuttmottaket på grunn av mistenkt/potensielt smittsom infeksjonssykdom i samme periode. 
Antall pasienter

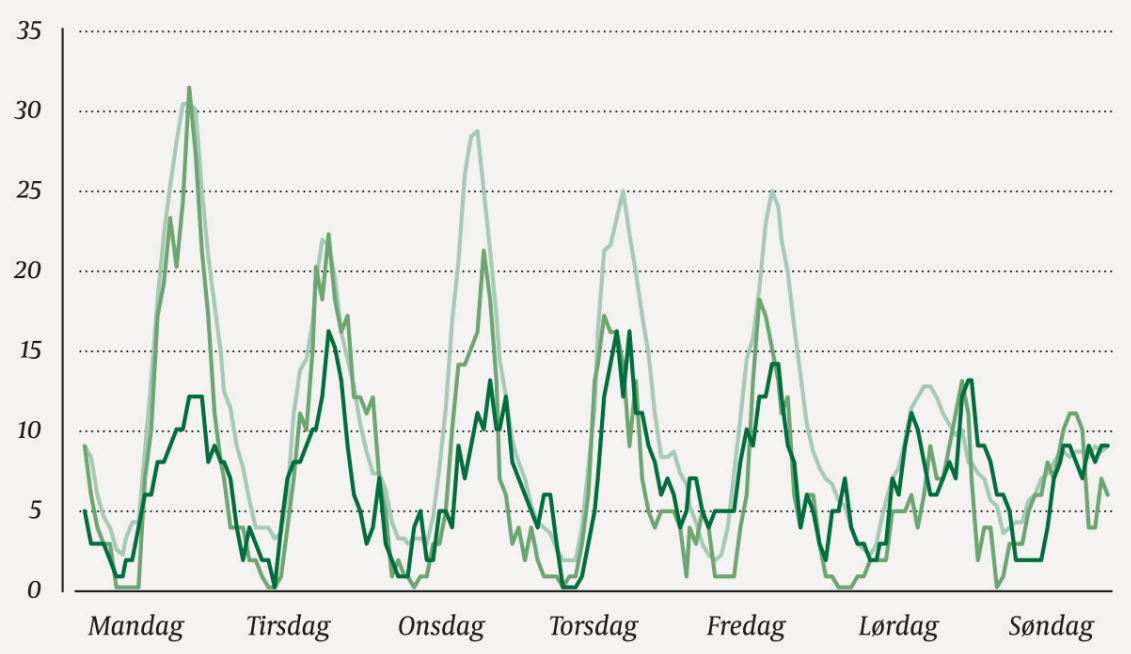

Figur 2 Antall inneliggende pasienter i akuttmottaket ved St. Olavs hospital hver hele time i uke 11 og 12 i 2020 sett opp mot gjennomsnittlig tilstrømming i uke 2-10 i 2020.

I uke 12 var det en generell reduksjon i akutte pasienter tilhørende alle fagområder. Reduksjonen for fagområdene medisin, kirurgi, ortopedi og nevrologi var på henholdsvis 98 (35\%), 49 (39\%), 16 (41\%) og 16 (40\%) pasienter sammenlignet med gjennomsnittet for uke 2-10. For hastegrad var det en reduksjon for rød, oransje, gul og grønn på henholdsvis $23(39 \%), 84(41 \%), 87$ (36\%) og 13 pasienter (48\%). Pasienter som ble håndtert poliklinisk i akuttmottaket, var redusert med 76 pasienter (47\%). Antall pasienter som ble innlagt på intensivavdeling eller overvåkningsenhet, var uendret (data ikke vist).

Det var en tydelig økning i uke 11 og 12 av pasienter som ble smitteisolert i akuttmottaket på grunn av mistenkt/potensielt smittsom infeksjonssykdom (figur 1). Gjennomsnittlig oppholdstid for pasientene i akuttmottaket var $3 \mathrm{t} 14$ min i uke 2-10, 2 t 52 min i uke 11 og $3 \mathrm{t}$ 29 min i uke 12. Oppholdstid for pasienter som ble smitteisolert, var 5 t 1 min i uke 12 til tross for at belegget på sykehuset i uke 12 var på $65 \%$ (interne data fra St. Olavs hospital, PASrapporten Korpas).

\section{Diskusjon}

Vi fant en betydelig reduksjon i antall henviste pasienter til akuttmottaket tidlig $\mathrm{i}$ epidemien. Tilsvarende er rapportert under de to første ukene av epidemien i Italia (5) og i Kina, der man så en kraftig reduksjon i pasienter som søkte akutt tannlegebehandling (므). Det er likevel ingen studier der man beskriver denne trenden mer utførlig. Allerede fra uke 11 så vi en tydelig generell reduksjon i antall pasienter som ankom akuttmottaket, uten at noen fagområder utmerket seg. Andre europeiske land, som Belgia, Frankrike og Tyskland, viser til upubliserte data om en generell reduksjon i antallet pasienter som ankom akuttmottaket, spesielt blant pasienter med antatt mindre alvorlige tilstander (7.).

Vår studie avdekket en tilsvarende reduksjon i antall pasienter med lav hastegrad og pasienter som normalt blir ferdigbehandlet i akuttmottaket. I Norge kan dette bero på at den norske primærhelsetjenesten i stor grad har håndtert disse problemstillingene selv, eller at terskelen for henvisning til akuttmottaket nå er høynet i en krisesituasjon.

Primærhelsetjenesten gjør gode kliniske vurderinger som begrenser pasienttilstrømmingen. Det at pasienttilstrømmingen er nærmest uforandret i helgen når fastlegekontorene er stengt, kan underbygge dette (figur 2). 
En mer bekymringsverdig forklaringsmodell for det markante fallet er at pasienter avventer med å ta kontakt med fastlegen eller 113 i frykt for å bli smittet eller for å belaste helsevesenet unødig. Denne frykten deles av akuttleger fra bl.a. Belgia, Storbritannia og Frankrike. I Tyskland rapporteres det om en reduksjon i hjerneslag og hjerteinfarkt i akuttmottaket (7), og tilsvarende udokumenterte tilfeller har forekommet i Trondheim. Muligens for ikke å belaste helsevesenet eller av frykt for smitte har pasienter gjennomgått både hjerte- og hjerneinfarkter uten å søke hjelp innen behandlingsmessige tidsfrister.

Det er avgjørende at primærhelsetjenesten fungerer som portvokter og filter for spesialisthelsetjenesten. Samtidig må det formidles til allmennheten at folk må søke medisinsk hjelp så tidlig som mulig ved symptomer som kan være alvorlig sykdom.

Målet under pandemien er at alle pasienter skal få trygg og kvalitativt god vurdering og behandling i akuttmottaket, uavhengig av hvilken situasjon vi befinner oss i. Dette er utfordrende, da utredning og behandling av isolerte pasienter tar lenger tid og krever mer ressurser. Covid-19-hurtigtest $\mathrm{i}$ akuttmottaket vil trolig kunne redusere tid til avklaring $\mathrm{i}$ akuttmottaket. Den største potensielle utfordringen er derimot et tilstrekkelig antall helsepersonell (2). Selv om ingen ansatte på akuttmottaket foreløpig er i karantene, er risikoen stor for at helsepersonell blir indisponible. Det er stille før stormen i Trondheim, og akuttmottaket forbereder seg til storinnrykk av pasienter med antatt covid-19-sykdom.

\section{LITTERATUR}

1. Aavitsland P. Koronavirusepidemien vil ramme Norge. Tidsskr Nor Legeforen 2020; 140. doi: 10.4045/tidsskr.20.0077. [PubMed][CrossRef]

2. St. Olavs hospital. Beredskap. https://stolav.no/beredskap Lest 13.4.2020.

3. Bjørnsen LP, Uleberg O, Dale J. Patient visits to the emergency department at a Norwegian university hospital: variations in patient gender and age, timing of visits, and patient acuity. Emerg Med J 2013; 30: 462-6. [PubMed][CrossRef]

4. Widgren BR, Jourak M. Medical Emergency Triage and Treatment System (METTS): a new protocol in primary triage and secondary priority decision in emergency medicine. J Emerg Med 2011; 40: 6238. [PubMed][CrossRef]

5. Coen D, Paolillo C, Cavazza M et al. Chanigng emergency departmetn and hospital organization in response to a changing epidemic. Emergency Care Journal 2020; 16: 8969.

6. Guo H, Zhou Y, Liu X et al. The impact of the COVID-19 epidemic on the utilization of emergency dental services. J Dent Sci 2020; 15. doi:10.1016/j.jds.2020.02.002. [PubMed][CrossRef]

7. The European Society for Emergency Medicine. COVID-19 Webinar: a unique insight in highly impacted countries. Sharing experiences of high COVID-19 impact countries. https://academy.eusem.org/eusem/2020/covid-19/290502/session.speakers.covid19.webinar.a.unique.insight.in.highly.impacted.countries.html? $\mathrm{f}=\mathrm{menu}=8^{*}$ browseby $=8 *$ sortby $=2 *$ label $=19798$ Lest 13.4 .2020 .

Publisert: 24. april 2020. Tidsskr Nor Legeforen. DOI: 10.4045/tidsskr.20.0277

Mottatt 29.3.2020, første revisjon innsendt 14.4.2020, godkjent 21.4.2020.

Publisert under åpen tilgang CC BY-ND. Lastet ned fra tidsskriftet.no 26. april 2023. 